\title{
Functional Characterization of Three Mutations of the Endothelin B Receptor Gene in Patients With Hirschsprung's Disease: Evidence for Selective Loss of $G_{i}$ Coupling
}

\author{
Sébastien Fuchs, ${ }^{1}$ Jeanne Amiel, ${ }^{2}$ Sophie Claudel, ${ }^{1}$ Stanislas Lyonnet, ${ }^{2}$ Pierre Corvol, ${ }^{1}$ \\ and Florence Pinet ${ }^{1}$ \\ ${ }^{1}$ INSERM Unit 36, Collège de France, Paris, France \\ ${ }^{2}$ INSERM Unit 393, Hôpital Necker, Paris, France \\ Contributed by D. J. Weatherall. Accepted October 12, 2000.
}

\begin{abstract}
Background: Hirschsprung's disease (HSCR) is one the most common congenital intestinal disease. It leads to aganglionic megacolon in the early childhood. Several susceptibility genes have been identified : RET protooncogene and its ligand, glial cell derived neutrophic factor (GDNF), Sox 10, Endothelin-3 (EDN3) and its receptor B (EDNRB). EDNRB mutations are found in $5 \%$ of familial or sporadic HSCR. Only few EDNRB mutations found in HSCR have been explored and some of them seem to be non fonctional variants.

Materials and Methods: The properties of three mutant human endothelin $B$ receptor $\left(\mathrm{hET}_{\mathrm{B}}\right)(\mathrm{G} 5 \mathrm{~S}, \mathrm{R} 319 \mathrm{~W}$ and $\mathrm{P} 383 \mathrm{~L}$ ) in isolated HSCR were analyzed. Stable recombinant cells expressing the three mutants and the wild-type (WT) were established. The $\mathrm{hET}_{\mathrm{B}}$ receptors were characterized for ${ }^{125}$ I ET- 1 binding, ET- 1 induced signaling : calcium transient, AP-1 transcriptional factor activation and cAMP accumulation.
\end{abstract}

Results: Immunofluorescence experiments showed normal cellular distributions of the mutant G57S, R319W and WT $\mathrm{hET}_{\mathrm{B}}$ receptors. In contrast, the $\mathrm{P} 383 \mathrm{~L} \mathrm{hET}_{\mathrm{B}}$ mutant receptor was concentrated near the nucleus and essentially no ET-1 binding was detected. The two other mutants (G57S and R319W) bound ET-1 normally, induced calcium transients and activated the AP-1 pathway in the same way as wild type, but did not inhibit adenylate cy-

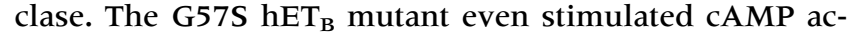
cumulation which was blocked by pertussis toxin.

Conclusion: The absence of the P383L mutant receptor from the membrane clearly indicates that this mutation could be involved in HSCR. The G57S and R319W mutant receptors, despite their normal coupling to $\mathrm{G}_{\alpha \mathrm{q}}$, have a defect in the $G_{\alpha \mathrm{i}}$ signaling pathway and the G57S mutation couples to $\mathrm{G}_{\alpha \mathrm{s}}$. These observations allow us to hypothesize that CAMP signaling might be involved in the differenciation of neural cells in the bowel.

\section{Introduction}

Hirschsprung's disease (HSCR) is a frequent congenital intestinal malformation affecting 1 in 5000 live births (1), characterized by the absence of ganglion cells in the distal portion of the intestinal tract. HSCR causes severe neonatal intestinal obstruction that requires surgical treatment, which currently ensures a favorable prognosis. The enteric nervous system is formed by the migration and differentiation of neural crest cells (2). HSCR is believed to be caused by the premature differentiation of these migrating neural crest cells before they reach the entire bowel (3).

Genetic and animal studies have uncovered several genes that make children susceptible to

Address correspondence and reprint requests to: Florence Pinet, INSERM Unit 36, Collège de France, 3 rue d'Ulm, 75005 Paris, France. Phone: 331442716 64. Fax: 331442716 91. E-mail: florence.pinet@college-de-france.fr
HSCR, two ligand/receptor pairs and a transcription factor. For a recent review see Chakravarti et al. (4). The gene that is most often mutated in HSCR is the RET protooncogene. There may also be mutations in its ligand gene: glial cell-derived neutrophic factor (GDNF) in HSCR $(5,6)$. The Sox 10 gene, which encodes a transcriptional factor expressed in neural crest cells, is mutated in some cases of aganglionic bowel (7) and its murine homologue (Dom) leads to dominant megacolon when mutated (8).

Endothelin (ET)-3 and its receptor $\mathrm{ET}_{\mathrm{B}}$ is another ligand/receptor combination that plays an important role in the development of the enteric nervous system (9). ET-3/ET $\mathrm{E}_{\mathrm{B}}$ inhibit the differentiation of neural crest cells. Both $\mathrm{ET}_{\mathrm{B}}$ and ET-3 are needed to prevent the premature differentiation of crest-derived cells that leads to aganglionosis (3). Mice with a targeted null disruption of either EDNRB or EDN3 have the same phenotype, coat colors spotting, and aganglionic megacolon, which is similar to those of 
"lethal spotted" and "piebald lethal" phenotypes in mice(10) and HSCR or Shah-Waardenburg syndrome in humans $(11,12)$.

The endothelins (ET-1, ET-2 and ET-3) are 21 amino acids, vasoactive peptides. They act via two distinct high-affinity endothelin receptor subtypes, $\mathrm{ET}_{\mathrm{A}}$ (13) and $\mathrm{ET}_{\mathrm{B}}$ (14), which are seven-transmembrane $\mathrm{G}$ protein-coupled receptors. The $\mathrm{ET}_{\mathrm{A}}$ receptor binds ET- 1 and ET-2, but not ET-3 at physiological concentrations, whereas $\mathrm{ET}_{\mathrm{B}}$ binds all three ETs with similar affinities.

Several mutations of EDNRB have also been reported in HSCR patients (15-21). But few studies to date have reported a functional analysis of the mutations identified. Three mutant $\mathrm{hET}_{\mathrm{B}}$ receptors were analyzed by Tanaka et al. (1998) (22). The N104I receptor had almost the same functional properties as the wild-type $\mathrm{hET}_{\mathrm{B}}$ receptor, the $\mathrm{Cl09R}$ receptor was not translocated into the plasma membrane and the S390R mutation impaired all intracellular signalings. A recent paper from Imamura et al. (23) described the impairment of $\mathrm{G}_{\mathrm{q}}$ coupling protein associated with the mutation W276A/C, whereas $G_{i}$ coupling was not affected.
We have examined the functionality of three mutant human $\mathrm{ET}_{\mathrm{B}}$ receptors. Amiel et al. (19) found these heterozygous $\mathrm{hET}_{\mathrm{B}}$ missense mutations (G57S, R319W and P383L) in isolated cases of Hirschsprung disease children. The three mutations correspond to three transitions, $\mathrm{G}$ to $\mathrm{A}$ at nucleotide $399, \mathrm{C}$ to $\mathrm{T}$ at nucleotide 1185 , and $\mathrm{C}$ to $\mathrm{T}$ at nucleotide 1378 . The first transition results in the substitution of glycine for serine at position 57 (G57S), the second in the substitution of arginine for tryptophan at position 319 (R319W), and the third for the substitution of a proline for leucine at position 383 (P383L). The G57S mutation is in the extracellular $\mathrm{N}$-terminal region of the $\mathrm{ET}_{\mathrm{B}}$ receptor, $\mathrm{R} 319 \mathrm{~W}$ is within the third cytoplasmic loop and $\mathrm{P} 383 \mathrm{~L}$ is in the end of the seventh transmembrane domain (Fig. 1, top). Alignment with other species shows that the sequences surrounding the mutations $\mathrm{R} 319 \mathrm{~W}$ and $\mathrm{P} 383 \mathrm{~L}$ are highly conserved, contrasting with the G57S region (Fig. 1).

Each mutation occurs sporadically in HSCR patients and they are inherited from an asymptomatic carrier, the mother. We investigated the relationship between the G57S, R319W and P383L hET $_{B}$ mutant receptors described by Amiel et al. (19) and HSCR

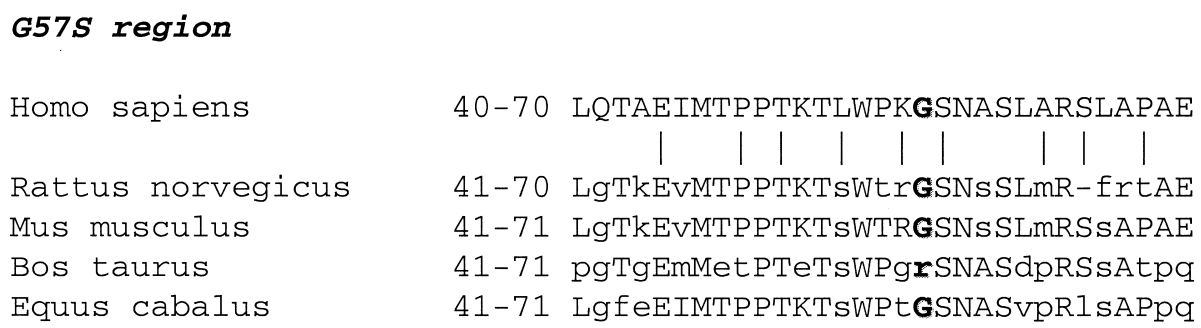

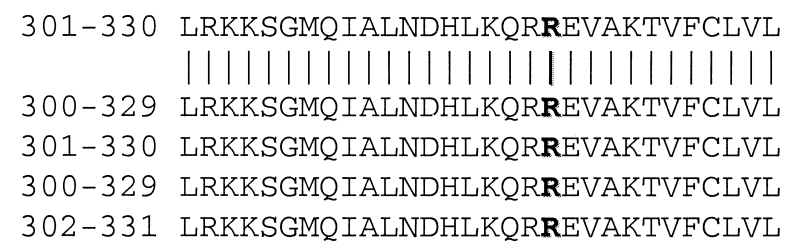

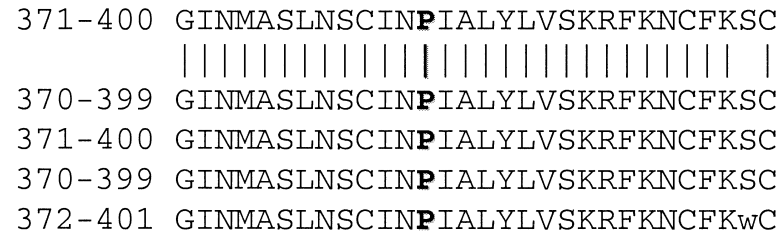

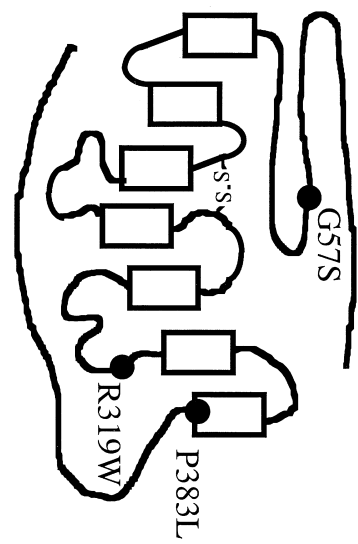

Fig. 1. Representation of the three mutant $\mathbf{h E T}_{B}$ receptors. Locations of the three mutations in a schematic representation of $\mathrm{ET}_{B}$ and sequence homologies between species-Comparisons of human (44), rat (45), mouse (10), bovine (46), and horse (47) $\mathrm{ET}_{\mathrm{B}}$ sequences using the programme MacVector. Sequences around the R319W and P383L mutations are highly conserved among species, whereas those around the G57S mutation are not. 
by analyzing the functional properties of these mutant $\mathrm{hET}_{\mathrm{B}}$ receptors using transfected wild-type or mutant $\mathrm{hET}_{\mathrm{B}}$ receptors into CHO and HEK-293 cells to study the signaling cascades of their activations.

\section{Experimental Procedures \\ Plasmid Constructs}

Human $\mathrm{ET}_{\mathrm{B}}\left(\mathrm{hET}_{\mathrm{B}}\right)$ cDNA (14) was subcloned into pcDNA $_{3}$ (Invitrogen $\left.{ }^{\circledR}\right)$ to create $\mathrm{pcDNA}_{3}-\mathrm{ET}_{\mathrm{B}}$. The 6xTRE-Coll-LUC plasmid (24) and pCH110 (25) have been described elsewhere.

The cDNAs encoding the mutant $\mathrm{hET}_{\mathrm{B}}$ receptors, G57S, R319W and P383L were constructed by sitedirected mutagenesis.

G57S SITE-DIRECTED MUTAGENESIS. The plasmid pcDNA $_{3}-$ G57S was constructed with two PCR amplified fragments using the following oligonucleotides: T7 59TAATACGACTCAACTAT AGGG-39 and G57S-Rev 59CCCGGGTGGCGTCATTATCTCTGCGGTTTG-39 to amplify the first fragment and oligonucleotides: G57S-Fr 59AGTACTAAGACCTTATGGC CCAAGAGTTCCA-39 and EcoRV-Rev59 AAGCAACAGCTCGATATCTGTCAA TAC-39 to amplify the second fragment. The first amplified PCR fragment was digested with BamHI and SmaI and the second with ScaI and EcoRV. The two digested fragments were then ligated by blunt end sites : Sma I and Sca I, and inserted into the plasmid pcDNA $_{3}$-ETB digested with BamHI and EcoRV to create pcDNA $3-$ G57S.

R319W SITE-DIRECTED MUTAGENESIS. The plasmid pcDNA $_{3}-\mathrm{R} 319 \mathrm{~W}$ was constructed with two PCR reactions, using EcoRV-Fr 59GTATTGACGATATCGAGCTGTTG-CTT-3' and R319W-Rev 5'-TTTTGGCCACTTCCCATCTCT-GCTTTAGGT-3' to amplify the first fragment, and R319W-Fr 5'-GCTTTAAATGATCACCTAAAGCAGAGATGGGA AGTGG-3' and EcoRI-Rev 5'-GCAGGAATTCAGTGAAG-CGAGTT$3^{\prime}$ to amplify the second fragment. These two PCR products were mixed and subjected to a new PCR reaction with the oligonucleotides EcoRV-Fr and EcoRI-Rev. The overlapped amplified fragment containing the mutation was then digested with EcoRI and EcoRV and inserted into pcDNA $\mathrm{pT}_{\mathrm{B}}$ plasmid digested with EcoRI/EcoRV to create pcDNA ${ }_{3}^{-}$ R319W.

P383L SITE-DIRECTED MUTAGENESIS. The plasmid encoding the mutation $\mathrm{P} 383 \mathrm{~L}$ in $\mathrm{hET}_{\mathrm{B}}$ receptor was named pcDNA 3 -P383L and created by fragment mutagenesis. The mutated fragment was amplified by PCR using the following oligonucleotides: P383L 59-TTCACTGAATTCCTGCATTAACCTAATTGCTCGTA-39 and SP6 59GCATTTA GGTGACACTATAGAATAG-39. The plasmid pcDNA $3-\mathrm{ET}_{\mathrm{B}}$ and the amplified fragment containing the mutation were digested with EcoRI and XbaI, and then ligated to create pcDNA 3 -P383L.
The plasmids corresponding to the different mutant $\mathrm{hET}_{\mathrm{B}}$ receptors were characterized by restriction enzyme analysis and verified by DNA sequencing on an ABI Prism 377 DNA Sequencer (PE Applied Biosystems).

\section{Cell Culture and Transfection}

Chinese hamster ovary (CHO) (ATCC n\&CRL 9606) were cultured in Ham's F-12 Nutrient Mixture (HAM F-12) (Gibco BRL) and HEK-293 cells (ATCC n\&CRL 1573) were cultured in Dulbecco's modified eagle medium (DMEM) (Gibco BRL), both supplemented with $10 \mathrm{nM}$ glutamine and $10 \%$ fetal calf serum (FCS), in a humified atmosphere of $5 \% \mathrm{CO}_{2}$ and $95 \%$ air. Cell transfections for transient and stable expression were performed using FuGENETM6 transfection reagent (Roche Diagnostics). For stable expression, $\mathrm{CHO}$ cells expressing the wild type (WT) and the mutant $\mathrm{hET}_{\mathrm{B}}$ receptors were grown in the presence of geneticin $(750 \mu \mathrm{g} / \mathrm{ml})$ to select the transfected cells. The resulting cloned cells were routinely cultured in the presence of $300 \mu \mathrm{g} / \mathrm{ml}$ geneticin.

CHO cells were made to stably express the aquorin gene (26) by Parnot et al. (27). These cells were then cultured routinely as described above for the other CHO recombinant cells.

\section{Radioligand Binding Assays}

The CHO cells expressing the WT or mutant $\mathrm{hET}_{\mathrm{B}}$ receptors were plated in 24-well plates for competitive binding experiments. They were incubated at $48 \mathrm{C}$ for $15 \mathrm{~min}$ in buffer A $(50 \mathrm{mM}$ Tris $\mathrm{HCl} \mathrm{pH} \mathrm{7.4,}$ $150 \mathrm{mM} \mathrm{NaCl}, 5 \mathrm{mM} \mathrm{MgCl}_{2}$ and $40 \mathrm{mg} / \mathrm{l}$ bacitracin) and then for $90 \mathrm{~min}$ at room temperature in buffer A containing $10 \mathrm{mg} / \mathrm{ml}$ bovine serum albumin (Sigma Aldrich), $50 \mu \mathrm{M}$ phosphoramidon (Sigma Aldrich) and ${ }^{125} \mathrm{I}$ ET-1 $\left(10^{6} \mathrm{cpm} / \mathrm{well}\right)$ (Amersham Pharmacia Biotech). Competition experiments were carried out with various concentrations of unlabeled ET-1, or the selective $\mathrm{ET}_{\mathrm{B}}$ agonist, succinyl-(Glu $\left.{ }^{9}, \mathrm{Ala}^{11,15}\right)$-endothelin-1(8-21) (IRL 1620) (28). Bound and free ligands were separated by washing cells 4 times with $50 \mathrm{mM}$ Tris$\mathrm{HCl} \mathrm{pH} 7.4$ at $48 \mathrm{C}$, and the cells were then counted in a gamma counter (TopCount, Packard) with $\mathrm{Mi}$ croscint 20 (Packard). Non-specific binding was defined as the binding measured in the presence of 100 nM unlabeled ET- 1

\section{Measurement of Calcium Transient}

Equorin containing CHO cells were grown in 96well plates and transiently transfected with cDNA encoding WT or mutant $\mathrm{hET}_{\mathrm{B}}$ receptors cDNA. Twenty-four hours later the cells were incubated for $120 \mathrm{~min}$ at $378 \mathrm{C}$ in $50 \mu \mathrm{l} / \mathrm{well}$ medium supplemented with $0.5 \mu \mathrm{M}$ colenterazine (Molecular Probes, Eugene USA), washed twice and then incubated for $30 \mathrm{~min}$ at room temperature in $50 \mu \mathrm{l}$ 
ÆQ buffer $\left(0.3 \mathrm{mM} \mathrm{CaCl}{ }_{2}, 1 \mathrm{mM} \mathrm{MgCl}_{2}, 125 \mathrm{mM}\right.$ $\mathrm{NaCl}, 5 \mathrm{mM} \mathrm{KCl}, 5.5 \mathrm{mM}$ glucose, $20 \mathrm{mM}$ Hepes, $\mathrm{pH}$ 7.3). Activation was performed by adding 50 $\mu$ ET-1 per well at various concentrations and counting luminescence $30 \mathrm{sec}$ later (TopCount, Packard).

\section{Characterization of AP-1 Pathway}

Recombinant CHO cell lines bearing the WT or the mutant $\mathrm{hET}_{\mathrm{B}}$ receptors were plated in 12-well plates and transiently transfected with $1.4 \mu$ l FuGENE ${ }^{\mathrm{TM}} 6$ transfection reagent, $0.5 \mu \mathrm{g}$ 6xTRE-Coll-LUC plasmid (24) and $200 \mathrm{ng}$ pCH110 (25) overnight. The culture medium was then changed and the cells stimulated with various concentrations of ET-1 or IRL 1620 (29) for 24 hours. The cells were washed three times with cold IX phosphate-buffered saline (PBS) and lysed with $200 \mu$ l Reporter Gene Assay Lysis Buffer (Roche Diagnostics). A $30 \mu \mathrm{l}$ aliquot was mixed with $30 \mu$ l Luciferase Reporter Buffer (PROMEGA) in a scintillation microplate and the luminescence was counted (TopCount, Packard) to measure luciferase activity. $\beta$-galactosidase activity was determined by measuring the luminescence of a $30 \mu \mathrm{l}$ aliquot using $\beta$-galactosidase Reporter Gene Assay (Roche Diagnostics).

\section{cAMP Accumulation Assay}

CHO and HEK-293 cells were grown in 24-well plates to $80 \%$ confluency and transfected with cDNA for WT or mutant $\mathrm{hET}_{\mathrm{B}}$ receptors for 48 hours. The cells were incubated for 2 hours in Kreb-Ringer buffer (10 mM Hepes, $118 \mathrm{mM} \mathrm{NaCl}, 2.5 \mathrm{mM} \mathrm{CaCl}_{2}$,

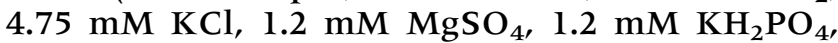
$24 \mathrm{mM} \mathrm{NaHCO}$, $11.1 \mathrm{mM}$ glucose, $0.3 \%$ BSA) at $378 \mathrm{C}$ and then in Kreb-Ringer buffer containing $10^{24} \mathrm{M}$ 3-isobutyl-1-methylxanthine (IBMX) (Sigma Aldrich) at $378 \mathrm{C}$ for $30 \mathrm{~min}$. The medium was then changed and the cells stimulated at $378 \mathrm{C}$ with various concentrations of ET- 1 in Kreb-Ringer solution containing $10^{24} \mathrm{M}$ IBMX for $30 \mathrm{~min}$. The medium was then removed and the cells were treated for 15 min with $1.5 \mathrm{ml}$ cold $65 \%$ ethanol on ice. One milliliter of ethanol was saved and dried in a SpeedVac. The cAMP contents were then measured by radioimmunoassay using the Biotrak $\left.{ }^{\mathrm{TM}} \mathrm{CAMP}^{125} \mathrm{I}\right]$ assay system (Amersham).

\section{Immunofluorescence}

The cells were fixed for 1 hour in $4 \%$ paraformaldehyde containing $3 \%$ sucrose and then immersed in $50 \%$ ethanol in PBS for $10 \mathrm{~min}$. They were blocked by incubation for 1 hour with $10 \%$ fetal calf serum in PBS, and then incubated with $4 \mu \mathrm{g} / \mathrm{ml}$ anti-hET ${ }_{\mathrm{B}}$ receptor antibody for 12 hours at $48 \mathrm{C}$. The antiserum was raised against a peptide (CLKFKANDHGYDNFRSSNKYSSS) corresponding to the carboxyl terminus (420-442) of the $\mathrm{hET}_{\mathrm{B}}$ receptor (30). The cells were washed and incubated in PBS containing $1 \%$ fetal calf serum and the Cy3-conjugated sheep antirabbit $\mathrm{F}\left(\mathrm{ab}^{\prime}\right)_{2}$ fragment antibody for 3 hours at room temperature. Fluorescent images were photographed under a microscope (Zeiss) and digitalized using a coolsnap camera (Kodak). Cells were treated with $10^{26}$ M ET- 1 for $30 \mathrm{~min}$ at $48 \mathrm{C}$, fixed and examined for internalization of WT and mutant $\mathrm{hET}_{\mathrm{B}}$ receptors.

\section{Results}

Affinities of the Wild-Type and Mutant $h E T_{B}$ Receptors for ET-1

We looked for the implication of these mutations in a predisposition to HSCR by examining their affinities for ET-1. We carried out competitive binding experiments using intact $\mathrm{CHO}$ cells transiently and permanently bearing WT or mutant $\mathrm{hET}_{\mathrm{B}}$ receptors. The specific binding of ET-1 to G57S and $\mathrm{R} 319 \mathrm{~W}$ receptors was similar to its binding to the $\mathrm{WT} \mathrm{hET}_{\mathrm{B}}$ receptor (Fig. 2). Untransfected CHO cells showed no specific binding. In competitive binding experiments unlabeled ET- 1 was similarly displaced from G57S, R3 19W and the WT $\mathrm{hET}_{\mathrm{B}}$ receptors. These results indicate that the affinities of G57S and R319W mutant receptors for ET-1 are very similar to those of the WT $\mathrm{hET}_{\mathrm{B}}$ receptor. In contrast, P383L mutant receptors bound ${ }^{125}$ I ET-1 very poorly (Fig. 2).

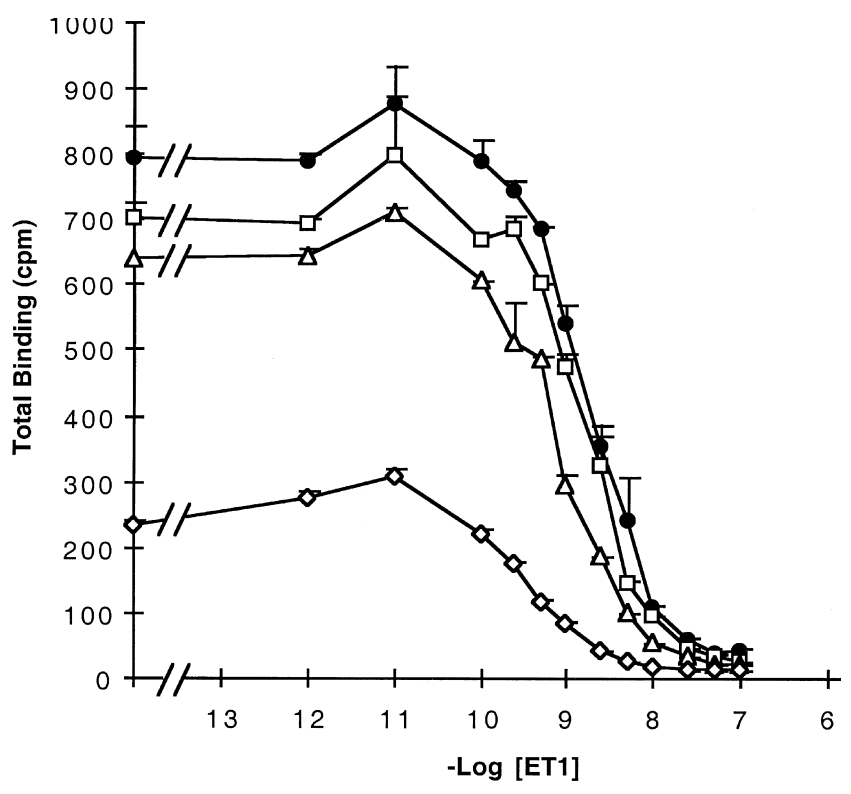

Fig. 2. Characterization of the recombinant $\mathrm{CHO}$ cell lines permanently bearing the WT or mutant hET $_{B}$ receptors. The binding assay was performed on intact cells using 100-pM labeled ${ }^{125}$ I ET-1. ${ }^{125}$ I ET- 1 binding to CHO cells bearing the WT $\mathrm{hET}_{\mathrm{B}}$ receptor $(\mathrm{d})$, or the mutant $\mathrm{hET}_{\mathrm{B}}$ receptors G57S $(\square)$, R319W $(\Delta)$ and P383L $(\diamond)$ was displaced with various concentrations of unlabeled ET-1. Results are expressed in counts per minute (cpm) and correspond to the means 6 SEM of triplicates. 
Subcellular Distributions of Wild-Type and Mutant $h E T_{B}$ Receptors in $\mathrm{CHO}$ Cells

CHO cells were immunostained with an anti-hET receptor antibody to show that the mRNAs for each receptor transfected were actually produced and translated. This antibody (30) was raised against a peptide (420-442) corresponding to the C-terminal part of the human $\mathrm{ET}_{\mathrm{B}}$ receptor and was used to determine the subcellular distributions of all the mutant receptors.

The synthesis and presence of the receptor was shown by immunostaining $\mathrm{CHO}$ cells transfected with the wild-type receptor or each of the three mutant receptors (Fig. 3). CHO cells transfected with empty pcDNA3 showed no immunostaining (not
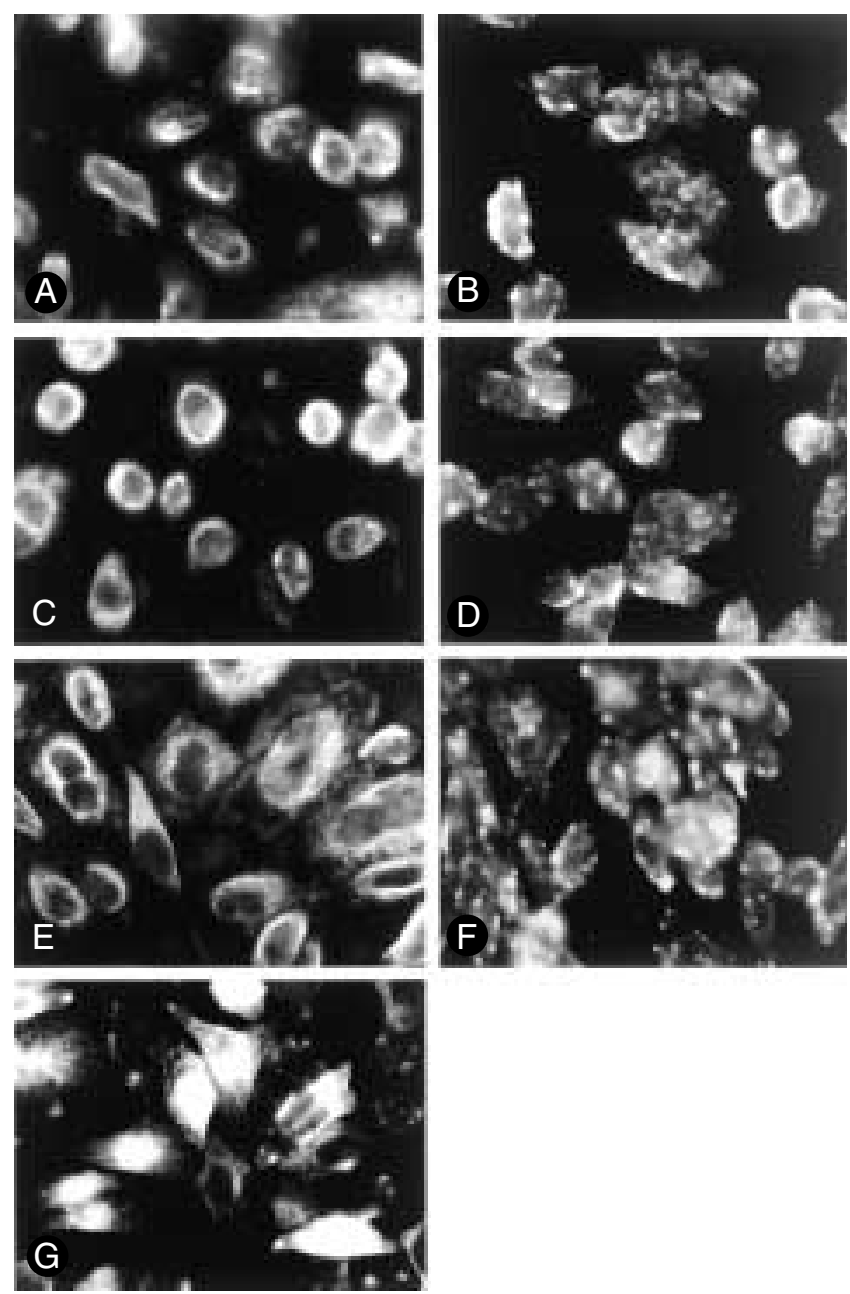

Fig. 3. Localization and internalization of $W T$ and mutant $\mathbf{h E T}_{B}$ receptors in $\mathbf{C H O}$ cells. $\mathrm{hET}_{\mathrm{B}}$ was detected using a specific antibody (30). The cells were fixed in $4 \%$ paraformaldehyde and permeabilized with $50 \%$ ethanol. (A,B) WT, (C,D) G57S, (E,F) R319W, and (G) P383L. For internalization, the cells were treated with $10^{26} \mathrm{M}$ ET-1 for $30 \mathrm{~min}$ at $48 \mathrm{C}$ before fixing and treatment. (B) WT, (D) G57S, and (F) R319W. Control reactions performed using untransfected $\mathrm{CHO}$ cells showed no staining (data not shown). shown). The distributions of the wild-type (Fig. 3A), G57S (Fig. 3C) and R319W (Fig. 3E) mutant hET receptors were all similarly diffusely distributed around the periphery of the cells. In contrast, the P383L mutant $\mathrm{hET}_{\mathrm{B}}$ receptor was observed near and around the nucleus (Fig. 3G), indicating limited access of ET- 1 .

The internalization of WT, G57S and R319W $\mathrm{hET}_{\mathrm{B}}$ receptors was analyzed by treating the cells with $10^{26} \mathrm{M}$ ET-1 for $30 \mathrm{~min}$ at $48 \mathrm{C}$ and immunostaining for ET-1. The wild-type (Fig. 3B), G57S (Fig. 3D) and R319W (Fig. 3F) mutant hET $_{B}$ receptors all behaved similarly; they were all in the cytoplasm of the cells with a punctuated distribution.

\section{Intracellular Signaling of the Mutant $h E T_{B}$ Receptors}

LIGAND-INDUCED INTRACELLULAR $\mathrm{CA}^{21}$ TRANSIENTS. Intracellular calcium transients were analyzed using CHO cells permanently containing æequorin in their cytoplasm (27). The binding of three calcium ions to the æequorin/cœlenterazine complex allows coelenterazine to be cleaved by æquorin, emitting light. The luminescence increases proportionally with the intracellular calcium concentration.

CHO cells producing æequorin were transiently transfected with the expression vectors encoding the wild-type, G57S, R319W or $\mathrm{P} 383 \mathrm{~L} \mathrm{hET}_{\mathrm{B}}$ receptors. The wild-type $\mathrm{hET}_{\mathrm{B}}$ receptor in $\mathrm{CHO}$-æquorin cells was activated by endothelin to produce a dosedependent intracellular calcium transient (Fig. 4).

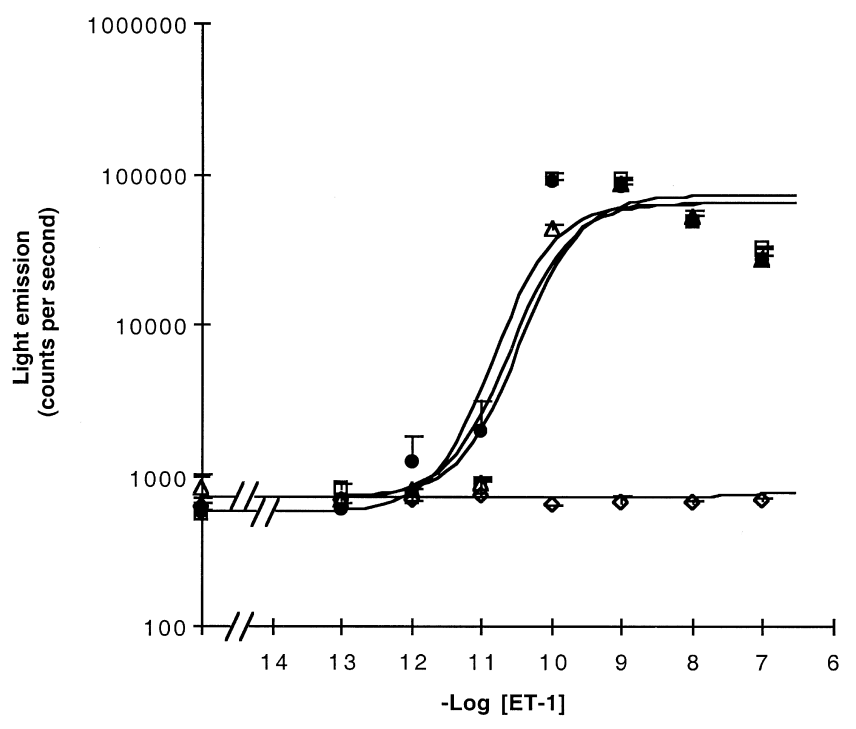

Fig. 4. Measurement of ET-1-induced calcium transients in CHO cells bearing WT and mutant hET $_{B}$ receptors. CHO cells producing æequorin (27) were transiently transfected with cDNA encoding WT (d), or mutant G57S $(\square)$, R319W $(\Delta)$ and P383L $(\diamond)$ hET $_{B}$ receptors. Light emission was measured immediately after stimulation with various concentrations of ET-1 in presence of colenterazine. The light emission measured is representative of the calcium transients. Results are expressed in counts per second (cps) and represent the means 6 SEM of three independent experiments. 


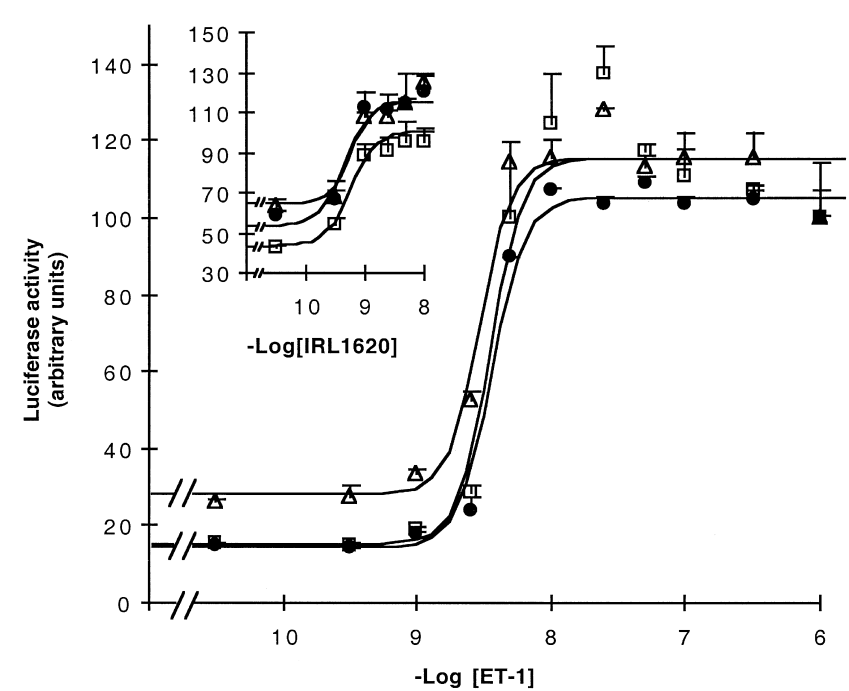

Fig. 5. Measurement of AP-1 pathway induced by activation of WT and mutant hET $_{B}$ receptors. CHO cells bearing WT (d), or mutant G57S $(\square)$ and R319W $(\triangle)$ hET $_{B}$ receptors were transiently transfected with the 6xTRE-Coll-LUC plasmid. The AP-1 pathway was induced by various concentrations of ET-1 or specific $\mathrm{ET}_{\mathrm{B}}$ agonist: IRL 1620 (inset). Luciferase activity is expressed as a percentage of the luminescence of $10^{26} \mathrm{M}$ agonist. Results are the means $6 \mathrm{SEM}$ of three independent experiments.

Activation was maximal with $10^{210} \mathrm{M}$ ET-1. The G57S and $\mathrm{R} 319 \mathrm{~W}$ mutant $\mathrm{hET}_{\mathrm{B}}$ receptors caused intracellular calcium transients in response to ET-1 stimulation similar to those of the WT $\mathrm{hET}_{\mathrm{B}}$ receptor, over a similar range of ET-1 (Fig. 4). In contrast, cells transfected with the $\mathrm{P} 383 \mathrm{~L} \mathrm{hET}_{\mathrm{B}}$ receptor produced no intracellular calcium transient when stimulated with ET-1, in agreement with its poor binding of ET-1 and its location (Fig. 2).

LIGAND-INDUCED AP-1 PATHWAY. Activation of the AP-1 pathway was measured using the ability of AP- 1 transcription factors to bind to the TRE (TPAresponsive element) sequence, which will activate the transcription of genes carrying this sequence in their promoter. CHO cells bearing WT or mutant $\mathrm{hET}_{\mathrm{B}}$ receptors were transfected with a luciferase reporter gene construct carrying 6 TRE sequences upstream of the minimal promoter of collagenase (24). The binding of agonist to its receptor activated the signaling pathway stimulating AP-1. The AP-1 then bound to the TRE sequences, and stimulated luciferase synthesis. The luciferase activity measured by luminescence was an indicator of AP-1 activation. ET-1 (Fig. 5) and the specific $\mathrm{ET}_{\mathrm{B}}$ agonist, IRL 1620 (insert panel Fig. 5) bound to the wild-type or the mutant G57S or $\mathrm{R} 319 \mathrm{~W} \mathrm{hET}_{\mathrm{B}}$ receptors and caused the same luciferase activity, indicating the same stimulation of the AP-1 pathway. The P383L receptor produced no stimulation of this pathway, either when stimulated with ET-1 or IRL 1620 (data not shown).

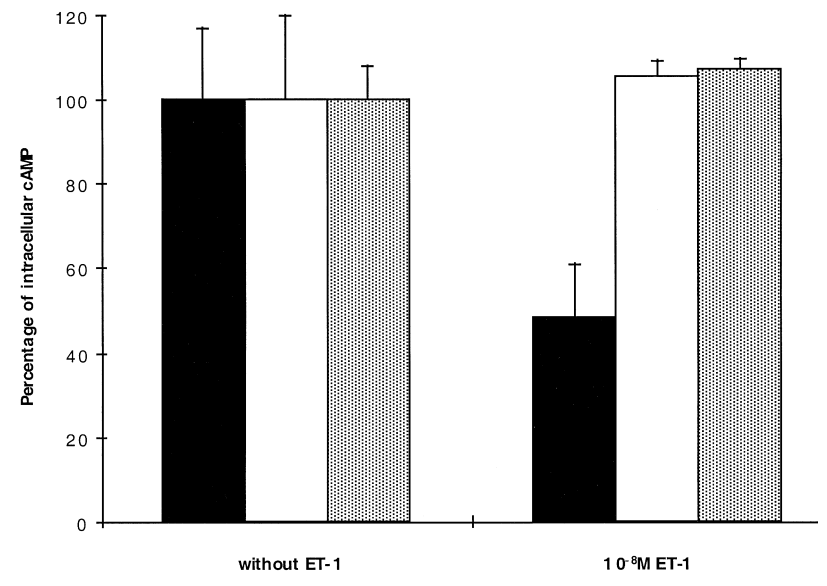

Fig. 6. Effects of ET-1 on cAMP accumulation in CHO cells bearing WT or mutant hET $_{B}$ receptors. Cells with WT receptor $(j)$ or mutant $\mathrm{hET}_{\mathrm{B}}$ receptors G57S $(\square)$ and $\mathrm{R} 319 \mathrm{~W}$ (j) were treated or not with $10^{2}{ }^{8} \mathrm{M}$ ET-1. Increasing concentrations of ET-1, from $10^{212}$ to $10^{26} \mathrm{M}$, had no effect on cAMP accumulation in cells transfected with G57S or R319W mutant $\mathrm{hET}_{\mathrm{B}}$ receptors (data not shown). The intracellular cAMP was determined by RIA, and the values are expressed as percentage of the basal cAMP accumulation. Results are the means 6 SEM of three independent experiments.

LIGAND-INDUCED ADENYLYL CYCLASE ACTIVITY. ET-1 inhibited adenylate cyclase in a dose dependent manner on CHO cells transiently transfected to produce the wild-type $\mathrm{hET}_{\mathrm{B}}$ receptor. This occurred after stimulation with $10^{25} \mathrm{M}$ forskolin (data not shown) and in basal conditions (Fig. 6). In contrast, neither G57S nor R319W mutant hET $\mathrm{B}_{\mathrm{B}}$ receptors inhibited the accumulation of cAMP in CHO cells in response to ET-1, with or without forskolin stimulation. Comparable results were obtained using CHO cells stably transfected with genes for WT and mutant hETB receptors (data not shown).

The same results were obtained in HEK-293 cells transiently transfected with genes encoding the wild-type and $\mathrm{R} 319 \mathrm{~W} \mathrm{hET}_{\mathrm{B}}$ receptors (Fig. 7A). The G57S $h_{B} T_{B}$ receptor even caused an increase in cAMP accumulation in response to ET-1 (Fig. 7A) that was blocked by treating the HEK-293 cells with pertussis toxin (Fig. 7B). As a control, pertussis toxin has no effect on the ET-1 blockade of adenylyl cyclase production via the wild-type $\mathrm{hET}_{B}$ receptor (Fig. 7B).

\section{Discussion}

We analyzed three new mutant $\mathrm{hET}_{\mathrm{B}}$ receptors that have been found in sporadic HSCR patients. The mutation in each case was heterozygous and inherited from an asymptomatic carrier (19). We explored their functionalities to determine whether these natural mutated receptors were involved in HSCR. The data also provide new information on the relationship 

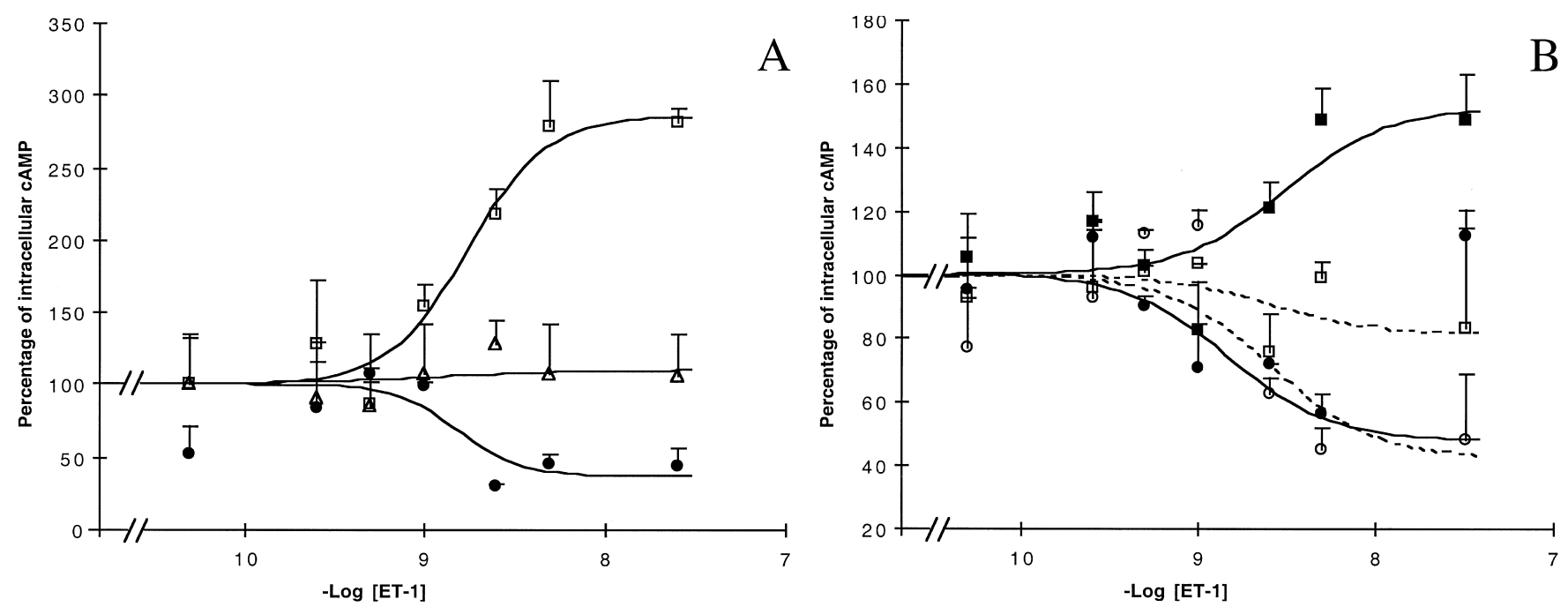

Fig. 7. Effects of ET-1 on cAMP accumulation in HEK-293 cells bearing WT or mutant hET $_{B}$ receptors. (A) Cells bearing WT receptor $(d)$ or mutant hET $_{B}$ receptors G57S $(\square)$ and R319W $(\triangle)$ were treated with increasing concentrations of ET-1. (B) Cells with WT receptor $(d)$ or mutant hET $_{B}$ receptors G57S $(\square)$ were treated with increasing concentrations of ET-1 without (lines) or with pertussis toxin (dots). The intracellular contents of cAMP were determined as in Fig. 6.

between the structure and the function of $\mathrm{hET}_{\mathrm{B}}$ receptors.

Human $\mathrm{ET}_{\mathrm{B}}$ is a $\mathrm{G}$ protein-coupled receptor (GPCR) that binds all three endothelin peptides equally well and is involved in the intracellular signaling pathway via heterotrimeric $G$ proteins $(31,32)$. Sakamoto et al. (33) reported that the classic "message-address" concept can be used for the endothelin receptor interaction. Recently, Masaki et al. (34) proposed that the endothelin receptor has two functions, a "message" and an "address" function, with each function assigned to different domains of the receptor. Takasuka et al. (35) showed that the 29 amino acids of the N-terminal part, starting from Lys 73, are responsible for the formation of the stable ligand-receptor complex. Sakamoto et al. (33) demonstrated that the region containing the first transmembrane domain (TMD1) to TMD3 and the adjacent intracellular, and extracellular loops, and the TMD7 are involved in endothelin binding and that TMD4 to TMD6 and the adjacent loops are involved in the subtype selectivity. It was shown that the third intracellular loop contains the major determinants for the selective coupling of each endothelin receptor subtype. More recently, Vichi et al. (36) demonstrated that TMD7 regulates the AP-1 transcriptional pathway and that the cytoplasmic tail is important for coupling to G protein, as in many GPCR. The third intracellular loop and the TMD6 also appear to be involved in the G proteins interactions. Several $G$ proteins can be activated after $\mathrm{ET}_{\mathrm{B}}$ receptor stimulation. The major signaling pathway for $\mathrm{ET}_{\mathrm{B}}$ activation is an increase in intracellular calcium concentration after activation of phospholipase $\mathrm{C}$, which is stimulated by activation of a $G_{q / 11}$. It was also recently shown that $G_{\alpha 13}$ is implicated, which will activate a Jun N-terminal kinase (JNK) after the binding of $\mathrm{ET}$ to $\mathrm{ET}_{\mathrm{B}}$ receptor. The minor signaling pathway for $\mathrm{hET}_{\mathrm{B}}$ is activation of $\mathrm{G}_{\alpha \mathrm{i}}$, which inhibits adenylate cyclase.

In this report, we performed functional analysis of three new mutants of $\mathrm{hET}_{B}$ receptors based on analysis of their coupling to heterotrimeric G proteins. The intracellular signaling pathway involved was analyzed and compared to that of the wild-type $\mathrm{hET}_{\mathrm{B}}$ receptor.

The P383L mutant $\mathrm{hET}_{\mathrm{B}}$ receptor bound essentially no ET- 1 and had no functional activity (induction of calcium transient and AP-1 stimulation). This was explained by the lack of functional receptors at the plasma membrane. Immunofluorescence experiments showed that the protein resulting from mRNA translation clustered mainly around the nucleus. The P383L mutation that occured in the Cterminal region of TMD7 impaired the translocation of the mutant $\mathrm{hET}_{\mathrm{B}}$ receptor to the plasma membrane. Such ectopic $\mathrm{hET}_{\mathrm{B}}$ receptor clearly cannot bind its agonist and cannot transduce a functional signal. This mutation affects the spatial structure of the seventh transmembrane helix that might be the cause of the sequestration of the mutant receptor into the Golgi apparatus. Only one mutation of the $\mathrm{hET}_{\mathrm{B}}$ receptor has been previously found to have impaired translocation to the plasma membrane. This C109R mutation lies in the amino-terminal region of TMD 1 (22). We can speculate that both C109R and P383L mutations are involved in creating a topogenic region that allows the transport of the receptor from the endoplasmic reticulum to the plasma membrane. A recent paper by Vichi et al. (21) examined the functionality of the $\mathrm{P} 382 \mathrm{~K}$ mutant rat $\mathrm{ET}_{\mathrm{B}}$ receptor (corresponding to P383L in humans (Fig. 1) and 
found an impaired binding, as for the P383L mutant. But the immunofluorescence of transiently transfected cells with an antibody against a Tag sequence showed that the subcellular distribution of the mutant was normal, in contrast with our data. The discrepancy of the results could be due to the substituted aminoacid (from proline to lysine in the rat $\mathrm{ET}_{\mathrm{B}}$, and to leucine in the human $\mathrm{ET}_{\mathrm{B}}$ receptor), or from the antibodies used, in our case a specific antibody against $\mathrm{hET}_{\mathrm{B}}$ and in their case against a Tag sequence, or even from the Tag itself, which could alter the cellular trafficking of the receptor.

In contrast, the two other mutant receptors analyzed, G57S and R319W hET $_{\mathrm{B}}$ were distributed, like the wild-type, at the periphery of the transfected cells, showing the proper trafficking of the receptor from the endoplasmic reticulum to the plasma membrane. Immunofluorescent labeling of cells incubated for 30 min with ET-1 showed similar internalization of the mutants compared to the WT $\mathrm{hET}_{\mathrm{B}}$ receptor. ET-1 induced a patchy distribution both below the plasma membrane and around the nucleus, presumably being located in lysosomes in accordance with a recent paper of Abe et al. (37). Most of the properties of the two mutants G57S and R319W were identical to those of the WT receptor. The same binding of ${ }^{125} \mathrm{I}$ ET-1 was observed for both mutants and WT hET $\mathrm{B}_{\mathrm{B}}$ receptors, showing functional binding sites of ET- 1 . There were also no changes in affinity binding using the specific $\mathrm{ET}_{\mathrm{B}}$ agonist IRL 1620. We tested the effect of ET activation of $\mathrm{hET}_{\mathrm{B}}$ on the calcium transient using a recombinant $\mathrm{CHO}$ cell line containing æquorin. This allows us to measure the light emission in live cells caused by increasing intracellular calcium in response to activation of $\mathrm{hET}_{B}$ by ET-1 (27). As expected, there was no stimulation of calcium transient by the P383L mutant $\mathrm{hET}_{\mathrm{B}}$ receptor, in agreement with the non access of ET- 1 to the mutant receptor. In contrast, for G57S, R319W and WT $\mathrm{hET}_{\mathrm{B}}$ receptor all gave the same activation. These results show that there is normal coupling with $\mathrm{G}_{\alpha q / 11}$ of these mutant $\mathrm{hET}_{\mathrm{B}}$ receptors after activation by ET- $\mathrm{l}$.

Vichi et al. (36) have shown recently that some TMD7 mutants of the rat $\mathrm{ET}_{\mathrm{B}}$ receptor have normal ERK activation by ET- 1 but a reduced AP-1 transcriptional activation. We tested the activation of AP-1 transcription by the mutant G57S and R319W $\mathrm{hET}_{\mathrm{B}}$ receptors by transient transfection of an AP-l/ luciferase reporter construct. The two mutants gave the same activation as the wild-type human $\mathrm{ET}_{\mathrm{B}}$ receptor, showing a normal $\mathrm{G}_{\alpha q}$ coupling. G57S mutation is in the $\mathrm{N}$-terminal part of the receptor, which is believed to be responsible for the formation of a stable ligand-receptor complex, but which does not seem to be important for the signaling coupling. R319W mutation is located within the third intracytoplasmic loop which have been shown to be a major determinant of selective coupling of $\mathrm{ET}_{B}$ (32). ET- 1 and the specific $\mathrm{ET}_{\mathrm{B}}$ agonist, IRL 1620 interacted with both mutants to give the same activation of AP-1 transcription, showing that the mutations are not in the subdomains involved in the selectivity of ET subtypes (33).

ET-1 has opposite effects on cAMP formation when acting via ETA and $\mathrm{ET}_{\mathrm{B}}$, with pharmacological evidence for the selective coupling of each receptor subtype with $\mathrm{G}_{\alpha \mathrm{s} / \alpha \mathrm{i}}(32)$. The effect of ET-1 on cAMP accumulation was tested on G57S and R319W and compared to the WT $\mathrm{hET}_{\mathrm{B}}$ receptors. Neither G57S nor $\mathrm{R} 319 \mathrm{~W} \mathrm{hET}_{\mathrm{B}}$ mutant receptors inhibited cAMP accumulation in the $\mathrm{CHO}$ cells, expressing transiently or permanently the mutant receptors. As CHO cells have low level of $\mathrm{G}_{\alpha \mathrm{s} / \alpha \mathrm{i}}$, WT and mutant $\mathrm{hET}_{\mathrm{B}}$ receptors were also transfected into HEK-293 cells. Furthermore HEK-293 cells are derived from human embryonic kidney and might have a better transduction of human endothelin receptor. Activation of the G57S mutant $\mathrm{hET}_{\mathrm{B}}$ receptor by ET-1 stimulated cAMP accumulation in HEK-293 cells, and the accumulation was blocked by pertussis toxin. Mutation G57S caused a switch of the G protein coupling from $\mathrm{G}_{\alpha \mathrm{i}}$ to $\mathrm{G}_{\alpha \mathrm{s}}$. WT and R319W mutant $\mathrm{hET}_{\mathrm{B}}$ receptors have the same type of responses in CHO cells and HEK-293 cells. Arg319 lies within the third intracellular loop where other mutations have been associated with HSCR, such as Ser305 (38). This loop might be important for the interaction of the $\mathrm{ET}_{\mathrm{B}}$ receptor with $\mathrm{G}_{\alpha \mathrm{i}}$ protein involved in the cAMP pathway, whereas it might not affect the $\mathrm{G}_{\mathrm{q}}$ protein that is said to cause the intracellular calcium transient and activate AP-1 pathway (39). A mutation in an other GPCR, the parathyroid hormone (PTH)/PTH-related peptide (PTHrp) receptor, results in a selective loss of a signaling pathway (40). Mutations in the second cytoplasmic loop of the PTH/PTHrp receptor cause a selective loss of PTH-stimulated phospholipase $\mathrm{C}$ activity without affecting the cells's capacity to generate cAMP.

The three mutations of the $\mathrm{hET}_{\mathrm{B}}$ receptor explored in this paper impair the subcellular distribution of the receptor (P383L) or the cAMP signaling pathway (G57S and R319W). Thus the P383L hET receptor mutation can be involved in HSCR. The links between the two other $\mathrm{hET}_{\mathrm{B}}$ receptor mutations (G57S and R319W) and HSCR are less clear. The G57S mutation has also been found in ECTIM population with a low frequency (12 carriers in 1223 individuals), but not associated with blood pressure or hypertension (41), which could be explained by the normal $G_{\alpha q}$ coupling of this mutant receptor.

Our findings allow us to make the hypothesize that a defect in the $G_{\alpha i}$ signaling pathway of the $\mathrm{hET}_{\mathrm{B}}$ receptor might be involved in HSCR etiology. The heterozygosity of the human $\mathrm{ET}_{\mathrm{B}}$ receptor would predispose to isolated HSCR with incomplete penetrance and $\mathrm{ET}_{\mathrm{B}}$ may be a susceptibility locus in non-syndromic HSCR.

The absence of ganglion cells from the distal portion of the intestinal tract in HSCR is a consequence of the premature arrest of the cranio-caudal 
migration of neural crest cells (9). The proposed explanation of this phenomenon is that $\mathrm{ET} / \mathrm{ET}_{\mathrm{B}}$ prevents the differentiation of neural crest-derived precursors during their migration (3). Furthermore, cyclic AMP has been shown to induce cell differentiation of Trypanosoma cruzi $(42,43)$. Taken together this suggests that the intracellular signaling of $\mathrm{hET}_{\mathrm{B}}$ receptors via cAMP might be involved in neural crest cell differentiation into neurons and glial cells induced by GDNF/RET protooncogene.

\section{Acknowledgments}

We thank J. Philippe for technical assistance, Dr C. Parnot for the gift of CHO cells expressing æquorin, and Dr Sasaki (Ciba Geigy, Japan) for the gift of hET receptors antibodies.

S. Fuchs received funds from the "Ministère de la Recherche et de l'Enseignement Supérieur". This work was supported in part by the "Ministère de la Recherche et de l'Enseignement Supérieur" (ACC-SV9). The English text was edited by Owen Parkes.

\section{References}

1. Lesser PB, El-Nahas AM, Lukl P, Andrews P, Schuler JG, Filtzer HS. (1979) Adult-onset Hirschsprung's disease. JAMA 242: 747-748.

2. Le Douarin NM, Teillet MA. (1974) Experimental analysis of the migration and differentiation of neuroblasts of the autonomic nervous system and of neurectodermal mesenchymal derivatives, using a biological cell marking technique. Dev. Biol. 41: 162-184.

3. Wu JJ, Chen JX, Rothman TP, Gershon MD. (1999) Inhibition of in vitro enteric neuronal development by endothelin3: mediation by endothelin B receptors. Development 126: 1161-1173.

4. Chakravarti A, Lyonnet S. (2000) Hirschsprung disease. In: Scriver CR, Beaudet AL, Sly WS, Valle D, eds. Metabolic and Molecular Bases of Inherited Disease, 8th edition, McGraw Hill, New York.

5. Salomon R, Attie T, Pelet A, et al. (1996) Germline mutations of the RET ligand GDNF are not sufficient to cause Hirschsprung disease. Nat. Genet. 14: 345-347.

6. Angrist M, Bolk S, Halushka M, Lapchak PA, Chakravarti A. (1996) Germline mutations in glial cell line-derived neurotrophic factor (GDNF) and RET in a Hirschsprung disease patient. Nat. Genet. 14: 341-344.

7. Kuhlbrodt K, Schmidt C, Sock E, et al. (1998) Functional analysis of Sox 10 mutations found in human WaardenburgHirschsprung patients. J. Biol. Chem. 273: 23033-23038.

8. Kapur RP. (1999) Early death of neural crest cells is responsible for total enteric aganglionosis in Sox 10(Dom)/Sox 10(Dom) mouse embryos. Pediatr. Dev. Pathol. 2: 559-569.

9. Gershon MD. (1999) Endothelin and the development of the enteric nervous system. Clin. Exp. Pharmacol. Physiol. 26: 985-988.

10. Hosoda K, Hammer RE, Richardson JA, et al. (1994) Targeted and natural (piebald-lethal) mutations of endothelin-B receptor gene produce megacolon associated with spotted coat color in mice. Cell 79: 1267-1276.

11. Edery P, Attie T, Amiel J, et al. (1996) Mutation of the endothelin-3 gene in the Waardenburg-Hirschsprung disease (Shah-Waardenburg syndrome). Nat. Genet. 12: 442-444.

12. Hofstra RM, Osinga J, Tan-Sindhunata G, et al. (1996) A homozygous mutation in the endothelin-3 gene associated with a combined Waardenburg type 2 and Hirschsprung phenotype (Shah-Waardenburg syndrome). Nat. Genet. 12: 445-447.
13. Hosoda K, Nakao K, Hiroshi A, et al. (1991) Cloning and expression of human endothelin-1 receptor cDNA. FEBS Lett. 287: 23-26.

14. Sakamoto A, Yanagisawa M, Sakurai T, Takuwa Y, Yanagisawa H, Masaki T. (1991) Cloning and functional expression of human cDNA for the $\mathrm{ET}_{\mathrm{B}}$ endothelin receptor. Biochem. Biophys. Res. Commun. 178: 656-663.

15. Puffenberger EG, Hosoda K, Washington SS, et al. (1994) A missense mutation of the endothelin-B receptor gene in multigenic Hirschsprung's disease. Cell 79: 1257-1266.

16. Attie T, Till M, Pelet A, et al. (1995) Mutation of the endothelin-receptor B gene in Waardenburg-Hirschsprung disease. Hum. Mol. Genet. 4: 2407-2409.

17. Kusafuka T, Wang Y, Puri P. (1996) Novel mutations of the endothelin-B receptor gene in isolated patients with Hirschsprung's disease. Hum. Mol. Genet. 5: 347-349.

18. Auricchio A, Casari G, Staiano A, Ballabio A. (1996) Endothelin-B receptor mutations in patients with isolated Hirschsprung disease from a non-inbred population. Hum. Mol. Genet. 5: 351-354.

19. Amiel J, Attie T, Jan D, et al. (1996) Heterozygous endothelin receptor $B$ (EDNRB) mutations in isolated Hirschsprung disease. Hum. Mol. Genet. 5: 355-357.

20. Svensson PJ, Anvret M, Molander ML, Nordenskjold A. (1998) Phenotypic variation in a family with mutations in two Hirschsprung-related genes (RET and endothelin receptor B). Hum. Genet. 103: 145-148.

21. Syrris P, Carter ND, Patton MA. (1999) Novel nonsense mutation of the endothelin-B receptor gene in a family with Waardenburg-Hirschsprung disease. Am. J. Med. Genet. 87: 69-71.

22. Tanaka H, Moroi K, Iwai J, et al. (1998) Novel mutations of the endothelin $B$ receptor gene in patients with Hirschsprung's disease and their characterization. J. Biol. Chem. 273: 11378-11383.

23. Imamura F, Arimoto I, Fujiyoshi Y, Doi T. (2000) W276 mutation in the endothelin receptor subtype $\mathrm{B}$ impairs $\mathrm{Gq}$ coupling but not Gi or Go coupling. Biochemistry 39: 686692 .

24. Parnot C, Le Moullec JM, Cousin MA, Guedin D, Corvol P, Pinet F. (1997) A live-Cell assay for studying extracellular and intracellular endothelin-converting enzyme activity. Hy pertension 30: 837-844.

25. Hall CV, Jacob PE, Ringold GM, Lee F. (1983) Expression and regulation of Escherichia coli lacz gene fusions in mammalian cells. J. Mol. Appl. Genet. 2: 101-109.

26. Rizzuto R, Simpson AW, Brini M, Pozzan T. (1992) Rapid changes of mitochondrial $\mathrm{Ca} 21$ revealed by specifically targeted recombinant aequorin [published erratum appears in Nature 360(6406):768, 1992]. Nature 358: 325-327.

27. Parnot C, Bardin S, Miserey-Lenkei S, Guedin D, Corvol P, Clauser E. (2000) Systematic identification of mutations that constitutively activate the angiotensin II ATlA receptor by screening a randomly mutated cDNA library with an original pharmacological bioassay. Proc. Natl. Acad. Sci. U.S.A. 97: 76157620.

28. Takai M, Umemura I, Yamasaki K, et al. (1992) A potent and specific agonist, Suc-[Glu9,Alal1,15]-endothelin-1(8-21), IRL 1620, for the $\mathrm{ET}_{\mathrm{B}}$ receptor. Biochem. Biophys. Res. Commun. 184: 953-959.

29. Baynash AG, Hosoda K, Giaid A, et al. (1994) Interaction of endothelin-3 with endothelin-B receptor is essential for development of epidermal melanocytes and enteric neurons. Cell 79: 1277-1285.

30. Sasaki Y, Hori S, Oda K, Okada T, Takimoto M. (1998) Both $\mathrm{ET}(\mathrm{A})$ and $\mathrm{ET}(\mathrm{B})$ receptors are involved in mitogen-activated protein kinase activation and DNA synthesis of astrocytes: study using ET(B) receptor-deficient rats (aganglionosis rats). Eur. J. Neurosci. 10: 2984-2993.

31. Aramori I, Nakanishi S. (1992) Coupling of two endothelin receptor subtypes to differing signal transduction in transfected Chinese hamster ovary cells. J. Biol. Chem. 267: 12468-12474.

32. Takagi Y, Ninomiya H, Sakamoto A, Miwa S, Masaki T. (1995) Structural basis of $G$ protein specificity of human 
endothelin receptors. A study with endothelin A/B chimeras. J. Biol. Chem. 270: 10072-10078.

33. Sakamoto A, Yanagisawa M, Sakurai T, et al. (1993) The ligand-receptor interactions of the endothelin systems are mediated by distinct "message" and "address" domains. $J$. Cardiovasc. Pharmacol. 22: S113-S116.

34. Masaki T, Ninomiya H, Sakamoto A, Okamoto Y. (1999) Structural basis of the function of endothelin receptor. Mol. Cell. Biochem. 190: 153-156.

35. Takasuka T, Sakurai T, Goto K, Furuichi Y, Watanabe T. (1994) Human endothelin receptor ETB. Amino acid sequence requirements for super stable complex formation with its ligand. J. Biol. Chem. 269: 7509-7513.

36. Vichi P, Whelchel A, Posada J. (1999) Transmembrane helix 7 of the endothelin B receptor regulates downstream signaling. J. Biol. Chem. 274: 10331-10338.

37. Abe Y, Nakayama K, Yamanaka A, Sakurai T, Goto K. (2000) Subtype-specific trafficking of endothelin receptors. J. Biol. Chem. 275: 8664-8671.

38. Auricchio A, Griseri P, Carpentieri ML, et al. (1999) Double heterozygosity for a RET substitution interfering with splicing and an EDNRB missense mutation in Hirschsprung disease [in process citation]. Am. J. Hum. Genet. 64: 1216-1221.

39. Sokolovsky M. (1995) Endothelin receptor heterogeneity, G-proteins, and signaling via cAMP and cGMP cascades. cell Mol. Neurobiol. 15: 561-571.

40. Iida-Klein A, Guo J, Takemura M, et al. (1997) Mutations in the second cytoplasmic loop of the rat parathyroid hormone $(\mathrm{PTH}) / \mathrm{PTH}-$ related protein receptor result in selective loss of
PTH-stimulated phospholipase C activity. J. Biol. Chem. 272: 6882-6889.

41. Nicaud V, Poirier O, Behague I, et al. (1999) Polymorphisms of the endothelin- $\mathrm{A}$ and $-\mathrm{B}$ receptor genes in relation to blood pressure and myocardial infarction: The Etude Cas-Temoins sur l'Infarctus du Myocarde (ECTIM) Study. Am. J. Hypertens. 12: 304-310.

42. Gonzales-Perdomo M, Romero P, Goldenberg S. (1988) Cyclic AMP and adenylate cyclase activators stimulate Trypanosoma cruzi differentiation. Exp. Parasitol. 66: 205212.

43. Rangel-Aldao R, Triana F, Fernandez V, Comach G, Abate $T$, Montoreano R. (1988) Cyclic AMP as an inducer of the cell differentiation of Trypanosoma cruzi. Biochem. Int. 17:337-344.

44. Nakamuta M, Takayanagi R, Sakai Y, et al. (1991) Cloning and sequence analysis of a cDNA encoding human non-selective type of endothelin receptor. Biochem. Biophys. Res. Commun. 177: 34-39.

45. Sakurai T, Yanagisawa M, Takuwa Y, et al. (1990) Cloning of a cDNA encoding a non-isopeptide-selective subtype of the endothelin receptor [see comments]. Nature 348: 732- 735.

46. Saito Y, Mizuno T, Itakura M, et al. (1991) Primary structure of bovine endothelin ETB receptor and identification of signal peptidase and metal proteinase cleavage sites. J. Biol. Chem. 266: 23433-23437.

47. Santschi EM, Purdy AK, Valberg SJ, Vrotsos PD, Kaese H, Mickelson JR. (1998) Endothelin receptor B polymorphism associated with lethal white foal syndrome in horses. Mamm. Genome 9: 306-309. 